\title{
STUDENT TEACHERS' PERCEPTIONS OF A WITS RURAL TEACHING EXPERIENCE PROJECT: WHAT TO LEARN AND IMPROVE
}

\author{
T. Nkambule \\ Curriculum Studies Division \\ University of the Witwatersrand \\ Johannesburg, South Africa \\ e-mail: Thabisile.nkambule@wits.ac.za
}

\section{ABSTRACT}

In South Africa all universities send education student teachers to schools for teaching practice as part of their preparation for teaching. Of concern is the lack of research investigating pre-service teachers' experiences of teaching practice, especially in rural and farm schools. Although several rural teaching practice projects have been established by various teacher education training institutions in South Africa, of concern and problematic for the article is knowledge gap that understand student teachers' perceptions and experiences after undertaking teaching practicum in rural schools. The article present student teachers' perceptions of Wits rural teaching practicum, and use a qualitative approach, semi-structured reflective discussions, and reflective journals to collect data. The findings show that education student teachers want to be part of the rural community and schools, rather than being 'tourists' and 'scientists'. Collaboration between preservice and in-service teachers is identified as crucial to share teaching skills and mentor new teachers.

Keywords: pre-service teachers, in-service teachers, rural schools, teaching experience, perceptions, university

\section{INTRODUCTION}

\section{RURAL AND FARM STUDENT TEACHING PRACTICE PROJECTS}

Several rural teaching practice projects have been established recently by various teacher education training institutions in order to introduce student teachers to rurality and rural and farm schools. These include students from urban, township, and rural and farm areas, because for the latter group being a learner and pre-service teacher in the same context is not the same. For example, in 2008 Balfour, Mitchell, and Moletsane launched a project entitled the Rural Teacher Education Project (RTEP) in the Faculty of Education at the University of KwaZuluNatal (UKZN), and selected a group of third- and fourth-year students in the Bachelor of Education at UKZN (South Africa) to do teaching practice in rural schools (Balfour, Mitchell 
and Moletsane 2008). There are two projects at the University of the Witwatersrand School of Education: the Kwena project in Mpumalanga province that was established in 2004 and takes student teachers to farm schools where they experience multi-grade classrooms and teaching, and the Wits Rural Teaching Experience (WRTE) that was established in 2012. The latter is an extension of the former project and was initiated with the objectives for student teachers to explore everyday life and make certain that they appreciate the rural space in all its diversity and complexity, to examine possible challenges and solutions experienced when working in rural schools, to acquire skills and knowledge that would prepare them to teach in rural contexts (Masinire, Maringe and Nkambule 2014). The Nelson Mandela Metropolitan University places pre-service teachers in rural contexts to try out visual participatory methodologies, to teach in 'new' ways that might make a difference and simultaneously expose the student teachers to a rural school context (De Lange, Khau and Athiemoolam 2014).

The introduction of these projects suggests acknowledgement by some teacher education institutions of varied school contexts and pedagogies, and the importance making students aware of them. Junqueira and Matoti (2013) state that teacher training programmes must include exposure to authentic as well as context-based teaching experiences and situations to enable student teachers to develop practical skills and human relationships. This means practical skills and human relationships that promote place and space consciousness, to ensure that student teachers do not generalise social and school contexts but acknowledge the differences that might require different interactional and pedagogical approaches. In addition, and in relation to the objectives that were presented earlier, there are gaps in teacher education programmes as the literature suggest the importance of including social and professional aspects of teaching in rural contexts (Hudson and Hudson 2008), because to date the implementation of such programs by universities has been uncoordinated, random or limited (Wright and Osborne 2007; White and Reid 2008). Without singling out and homogenising rural contexts, it is also important for teacher education programmes to acknowledge that for effective teaching practices in rural schools, teachers with good professional preparation are a catalyst not only for the provision of quality education in rural schools but also in terms of national development (Lingam 2012; UNESCO 1995). Thus teaching in rural settings ostensibly require relevant knowledge and skills to cope with various eventualities and challenges (Field 2001), and teacher's ability to meet the challenges and responsibilities of myriad work responsibilities depends to a large extent on their professional preparation. Both the theoretical and practical components of the training program need to be compatible with the work expected of teachers in schools such as those located in rural settings. Eppley (2009) suggest that besides possessing relevant teaching 
qualifications, being aware of the realities of rural life would help a teacher to appreciate the difficult situation in rural schools and thereby use suitable practical strategies to ensure children achieve optimum learning outcomes.

As long ago as 1966 Malassis argued that one of the main goals for rural and farm education should always be to provide quality education to improve the lives of people in rural and farm areas. This goal indicates that teacher education training institutions need to play an active role in producing quality teachers who are interested in teaching in rural and farm schools, and in providing quality education to the learners and the communities in which they live. Schafft and Jackson (2010) claim that the topic of rural and farm education is usually mentioned in passing, if mentioned at all, in teacher education training programmes, and never emerges as a topic of detailed discussion. Similarly, findings from research done by the Human Rights and Equal Opportunity Commission (HREOC) (2000) indicate that the majority of teacher education courses do not equip students with the skills and knowledge to teach in rural and remote locations. Student teachers have limited access to information about the lifestyles and challenges that are experienced in rural and farm communities, and which shape teaching and learning in schools in these communities. Different field experiences, according to Junqueira and Matoti (2013), give student teachers opportunities to evaluate their capabilities in those contexts, rather than one particular context that might be generalised. This article discusses education student teachers' perceptions of a Wits rural teaching experience project, in order to contribute information that can develop the project for the benefit of the rural and farm communities, student teachers, and teacher education programmes.

\section{TEACHING PRACTICE AND THE PROCESS OF BECOMING A TEACHER}

Which practices constitute effective teaching is the subject of unending debate (Good, McCaslin, Tsang, Zhang, Wiley and Bozack 2006). However, what is generally agreed is that teaching practice is an important element in the student teachers' initial education and development, making it important to understand and analyse the lived experiences of those who are learning to teach (Arends and Phurutse 2009). Currently, teaching practice is considered as not only including scientific, procedural and pedagogical components, but also components which focus on the cognition and emotions of the student teachers. It is imperative to listen to the dilemmas, doubts, fears and successes of the student teachers regarding their teaching practice (Caires, Almeida and Vieira 2012), particularly of those whose teaching practice is located in the marginalised contexts of rural and farms schools. It is also important to 
understand pre-service student teachers' motivations, beliefs and expectations about the profession, after practicing in rural and farm schools.

Despite the growth in knowledge about the process of becoming a teacher (Caires et al. 2012), several key questions remain unanswered or have been superficially approached. According to some authors, a deep and holistic understanding of this process may be compromised by the frequent disregard of its phenomenological and idiosyncratic aspects: 'Who' are these teacher candidates (their educational background, school biography/early school experiences, reasons for choosing the teaching profession)? 'How' do they experience their teaching practice (feelings, thoughts, and attitudes)? 'What' are their main difficulties and concerns while coping with the constraints and challenges of teaching practice and their teaching career? 'Which' conditions determine the positive/negative resolution of these difficulties and concerns? 'Who' are the student teachers' 'significant others' during this process? 'Which' gains do they most frequently perceive as resulting from their first encounter with teaching? (Caires et al. 2012). The phenomenological approach to understanding student teachers' reasons for becoming teachers and the experiences of becoming a teacher in different contexts is important, so as to be aware of issues and things that have been taken for granted and could enhance current practice that overlooks rural and farm contexts. The information could enable teacher education institutions to understand the complexity, diversity, richness and intensity of this phenomenon and address the different needs (e.g. technical, emotional, social, vocational) of the student teachers and the dynamics and paths that characterise the process of becoming a teacher.

Graham (2006) states that two components are critical to successful outcomes of the teaching practice experience, namely the mentor teachers who guide and support student teachers, and the sites where the experiences occur. Mentor teachers as practising professionals are aware of current issues in education, and are uniquely positioned to help student teachers navigate the demands of the practicum, particularly in matters of curriculum and classroom management (Maphalala 2013; Mukeredzi and Mandrona 2013). Student teachers are looking to their mentors for support through a period that is frequently stressful both emotionally and physically (Maphalala 2013), and it is thus important that mentor teachers model good practices of teaching. Student teachers, being new in rural school contexts, depend on professional teachers' experiences and guidance of the activities inside and outside the school and classroom. It is important that teaching and learning is understood in relation to the social context because of the reciprocal relationship, and in-service teachers are in a good position to mentor student teachers about the context holistically. 


\section{METHODOLOGY}

\section{Background to the research}

The research project discussed in this article investigated the experiences of a group of preservice teachers who chose to undertake teaching practice in Acornhoek, rural Mpumalanga province. In the Wits School of Education student teachers spend time in schools in May and September. The RTEP works with 10 or 11 second- and third-year primary and FET student teachers in each semester. The goal of the programme is to afford students the opportunity to explore resources and challenges of working in rural schools. It is further anticipated that student teachers will acquire the skills and knowledge that prepare them to teach in challenging rural and farm contexts.

In May 2014, 11 students were placed in two high schools, because all were specialising in the FET phase, and in May 2015, 10 students were placed in two high schools and two primary schools. Which means, seven students in high schools and three students in primary schools, and for the latter, two students in English medium and one Se-Tsonga primary school. From the beginning of the project students and supervising lecturers participated in detailed reflection sessions every Wednesday and Sundays, if students requested this. At these sessions students discussed their experiences in schools, including the nature of the classrooms, the culture of teaching and learning in the classrooms, learners' and teachers' relationships, relationships with supervising teachers, and school leadership. The data analysed in this article is taken from these student reflective discussions and journals, with their permission.

\section{Research participants}

There were 21 participants, drawn from second - and third - year foundation, intermediate, senior and FET phase student teachers. To participate in the project students were selected using their performance marks at the end of the year, and students with $65 \%$ overall and above were chosen. However, due to the limited amount of space, only students who achieved $70 \%$ and above were selected, and we believed they had appropriate content knowledge for the context. This means purposive sampling was used because research participants, including research sites, were chosen because of '... some defining characteristics that make them the holders of the data' (Maree 2007, 22). The defining characteristics for the students were being part of the RTEP project, and having experience of the rural context while doing teaching experience. We explained ${ }^{1}$ to all the students that the rural teaching experience project also included a research 
component and that their participation was voluntary, although it would be appreciated if all of them could participate. All students allowed their journals and recorded discussions to be used, stating that their information would assist in enhancing the project for other students. Students had different specialisations - Languages (especially English), Natural Science, Geography, and Economics (part of EMS). The project did not select students with specialisations in Maths Literacy, Mathematics and Science, and Technology, due to limited supervising lecturers with specialisation in these subjects.

\section{RESEARCH METHODS}

\section{Reflective discussions and journals}

For the purpose of data collection, group reflective discussions and students' reflective journals were used. According to Tsang (2011) students learn best by thinking, evaluating, integrating and internalising insights gained from their various teaching experiences. Reflective learning and reflective practice are believed to be salient in scholarly inquiry and underpin the construction of new knowledge and perspectives from experiences, leading to continual and enduring transformations (Dymant and O’Connell 2010; Mann, Gordon and MacLeod 2009). Due to the importance of the journals, students were encouraged to engage with their journals critically rather than superficially in order to gain an insight into their professional experiences in a rural context.

Group reflective discussions are classified as semi-structured because they do not strictly follow a particular structure. Although there are prepared questions to be discussed, anyone can speak when they have something to say. Others either add or disagree with the information given, depending on the student's interpretation of the situation being experienced. Students were allowed to discuss their experiences because of the variations and the richness of the information. All group reflective discussions were audio-recorded with the students' permission, to make sure that all information was captured and that I focussed on what they were saying rather than focussing on taking notes while they were talking.

\section{Reflective journals}

In the Wits School of Education all students are expected to keep a journal from first year to fourth year, to write reflections of their teaching experiences for all schools they attend. Tsang (2011) states that reflective journaling is among the most popular reflective tools used in undergraduate programmes, and for Wits Education students it is only during teaching 
experience that students write their experiences. Students were expected to write reflections on their rural teaching experience, and these have been used as data in this article because some students wrote more than they expressed themselves verbally. Students wrote in their journal every day, while reflective discussions took place mostly on Sundays afternoon. All students' reflections were photocopied with the student's permission, and filed.

\section{RESEARCH QUESTIONS}

The project was guided by three questions that were asked of students in all reflective discussion meetings of each teaching experience:

a) What are your perceptions and experiences of rural teaching experience since you arrived?

b) What do you think should be done to enhance teaching and learning in rural schools?

c) How can the Wits rural teaching experience be improved from its current practice?

\section{DATA ANALYSIS}

The initial preparation for data analysis required organisation of the enormous amount of information, because qualitative research often results in voluminous information gathered from the study (Creswell 2009). De Vos (2002, 339) states that data analysis is the process whereby 'the researcher brings structure and order to the vast amount of data collected, and looks for patterns in the data in order to make sense of it, leading to interpretation and meaningmaking'. Considering the data, with reflective discussions of two groups of students and 21 photocopied journals, this resulted in large amounts of information after the transcription of all reflective discussions. While I outsourced a transcriber for the recorded reflective discussions, I continued to listen to the discussions as I was coding, re-coding, and categorising the data until themes emerged. For the analysis of journals, the research questions were used to look for relevant information that addressed each question, and these questions were also analysed in relation to the reflective discussions. I noticed that some of the responses that were written in some journals were discussed, but of interest is that the discussions were more detailed than reflections in a journal.

\section{FINDINGS AND DISCUSSION}

In South Africa it is usual for students to be placed in schools for a period of six weeks in a year, and at Wits School of Education this period is divided into two three-week blocks. Considering this arrangement, it is unsurprising that the students thought of themselves as scientists or tourists who explore and leave a place. 


\section{‘... we are like science explorers ... I feel like a tourist'}

Rural teaching experience is perceived as different from urban teaching experience because when students are in Johannesburg they commute from the university residences or their homes to schools and travel by taxis, buses and trains. When students are doing teaching practice in Acornhoek schools they stay at Wits rural lodge, which is located approximately $5 \mathrm{kms}$ from the various schools. In the morning they are dropped at the schools and then fetched in the afternoon as soon as the school day ends. This means there is no opportunity for them to get to know the rural community or to engage with the community, as the following responses illustrate:

I was happy when I arrived here (Acornhoek) because I thought I will get to know the rural community, and understand how they do things as compared to townships. Unfortunately, we stayed at Wits rural facility that is far from the community, and no opportunity to engage with the community. For me it's like we are scientist that just come and do the research and go without interacting closely with the community, that need to change for us to have the rural real experience (Student group discussion session, September 2014).

Although this experience is good, but I feel like a tourist looking at the schools and talk with the teachers and learners only. We only go to the shops and back to Wits rural facility, no engagement with the community to talk about different issues of concern to them, for us to learn. Let's stay with families if security is a concern, so that we make fire in the morning before coming to school (Student group discussion session, May 2015).

The responses suggest that pre-service students problematised the concept of 'rural experience' because they did not interact with the community to learn ways of doing things from and with the community where schools are located. It was important for student teachers to interact with the community for their personal and social development, so that they know how to live and communicate with the community because the community had three different languages. To be isolated means there are restriction to learn and address 'cultural gaps' at the same time learn about the life style in the rural context, to possible address the stereotypes they might have had. Halsey (2009) has argued that, to assist in addressing the low numbers of teachers who choose to work in rural schools, student teachers need to be initiated into teaching and living in a rural community before they graduate. This mean 'consideration should be given to pre-service teacher education courses to cover teaching in rural areas', and also rural teaching practicum programme should be integrated in a teacher education programme at the universities.

Thus the interaction was possibly going to help pre-service teachers to make sense of their perceptions about the rural community, and also form 'relationships and understanding with others ... resulting in openness to new experiences' (Mayer, Salovey and Caruso 2004, 37). Unfortunately, the structure of Wits rural teaching experience makes students perceive 
themselves as 'science explorers and tourists' because they only interact with teachers and learners within the school context. There is no opportunity to interact ' ... with the children and talk about issues that worries them ...' (Student group discussion session, May 2015), get to know them from a different 'real' context. It appears that student teachers believe in the significance of gaining insight about learners' social issues in relation to the behaviour and worries in the school, thus functioning effectively in community service areas other than teaching. This response also addresses different authors' (Caires et al. 2012; Lamote and Engels 2010) argument of using the phenomenological approach to understanding student teachers' reasons for becoming teachers and the experiences of becoming a teacher in different contexts. The information can enable teacher education institutions to understand the complexity, diversity, richness and intensity of this phenomenon and to address the different needs (e.g., technical, emotional, social, vocational), of the student teachers and the dynamics and paths that characterise the process of becoming a teacher. It appears that students value interaction as the opportunity to learn more about the '... cultural and linguistic diversity as teaching tools in the classroom ...' (Lingam 2004, 6), and better ways to engage with the teachers and learners. This chance for the pre-service teachers would mean they have rural experience as they interacted with the community out of the school context, as a way of making sense of the lifestyles in rural area. This was a gap from the objectives that were stated earlier, because student teachers did not get to explore everyday life and not necessary appreciated the rural space in all its diversity and complexity due to distance accommodation to the community. Similarly, Butler (2013) agrees that exposing pre-service teachers to the realities of rural life (both good and bad) can be an effective, even necessary, strategy. Without this kind of exposure pre-service teachers may default to 'dominant narratives of rural deficits' which influence 'teaching identities, choices of employment opportunities to pursue, and their attitudes toward students and community members in rural communities’ (Eckert and Petrone 2013, 72).

In addition, pre-service students suggest the formation of a partnership between the university and the community, which is another form of interaction. Staying with families might be another way of making sense of the culture and the linguistic diversity in the community and also the challenges, while at the same time addressing their perceptions about rurality. To possibly make sense of some of the challenges experienced when working in rural schools is to realise the relationship that exist between the community and the school, and this was a gap in the objectives, and understanding the socio-cultural and economic situation would assist with thinking of the contextualised solutions. The importance of pre-service teachers to staying with families is supported by Lingam (2004) and Wenger and Dinsmore (2005) because it would 
help students to be more informed and appreciative of the simplicity of rural lifestyle. They would also learn 'various rural skills such as cooking on an open fire, cutting, collecting and storing firewood to enable student teachers to live successfully in rural areas' (Lingam 2004, 34). Students do not want to be 'isolated' but rather want to make a difference in the schools and community, and getting involved in everyday activities count as rural experience for preservice teachers.

\section{'... opportunities to be part of the community and to make a difference'}

It is evident from the critical comments about being 'science explorers' and 'tourists' and the proposal that they should stay in the community rather than at Wits rural lodge, that students recognised the possibility of being integrated into the community. They wanted to be a part of as well as assisting the community and schools:

At Thulasizwe School (not a real name) they requested that we assist them on Saturdays with maths, science, and English, because we can encourage their learners. That is one way of making a difference in a community, as we interact with learners we also understand the community (Student group discussion session, September 2014).

I want to interact with the children and talk about issues that worries them or challenges, and even positive stories we don't know about. It is easy to be bias about rural areas, because you don't necessarily know anything about them. You always hear about rural people from others, and usually paint a bad picture. It is important to learn about their culture, and gaining all this information will help me to know how to contribute, how to work with the community to make sense of challenges and good stories (Student group discussion session, May 2015).

The responses suggest the importance of addressing an individual's bias by engaging with different groups of people in the community, in order to make sense of the educational community. It is possibly easy to be bias and stereotypical about rural areas from urban community discourses, and doing community service and interacting with learners might address some of the negative stereotypes depicting rural schools as inferior and staffed by transient and inexperienced teachers (Boylan and McSwan 1998). In addition, the interaction with learners is important, to possibly address the notion of 'them' and 'us', which creates distance and makes immersion into the space challenging. The teacher education courses and programmes can play effective role by promoting innovative and cooperative endeavours to 'ensure that teacher education meets the needs of regional, rural and remote communities' (Lingam 2012) and develop programmes that familiarise preservice teachers with teaching in rural and remote contexts. From the responses, it appears that pre-service teachers do not want to be perceived as privileged and powerful because they come from urban areas and attend a university, instead they want to understand the significance of the context in shaping learners' 
decisions, behaviours, and choices. Britzman (2003) also states that the process of becoming a teacher involves the initiation of student teachers into the educational community, which is described as a dynamic and continuous process of mutual interactions and adaptation amongst the newly arrived teacher and the different members of that community. In addition, exposure and interaction help students to re-think their perceptions and 'dominant narratives of rural deficits' which influence 'teaching identities, choices of employment opportunities to pursue, and their attitudes toward students and community members in rural communities' (Butler 2013, 56). It is encouraging to hear students making positive statements about being part of the rural community because rural schools are better able to recruit teachers with previous exposure to or immersion in rural communities even if they are from urban areas (Miller 2012).

\section{SHARING TEACHING STRATEGIES AND CLASSROOM EXPERIENCES}

The concept of community engagement was extended to the sharing of teaching and classroom experiences as a way of improving learners' performance. Students' classroom experiences in the schools with learners and some with teachers made them suggest the importance of sharing classroom experiences and teaching strategies. Although students had been in schools for three weeks, they felt they had some information to share with in-service teachers regarding ways of improving learners' engagement during teaching and learning. Pre-service teachers shared their experiences with learners while teaching in the classroom:

... learners seems used to be given information and not participate in the classroom, because if you try and engage them in the lesson or ask questions they rarely respond. They are forever looking down at the textbook, I am not sure whether they are looking for answers or what (Student group discussion session, May 2015).

I noticed that the language of teaching and learning is a challenge for some learners, even grade 12s are struggling to express themselves in English. They prefer to answer in Se-Tshonga because they said English is difficult, and according to my colleagues it happens to other subjects (Student reflective journal, September 2014).

Teachers says learners do not want to read to improve their English, but I observed two teachers using Se-Tshonga to explain natural science and technology. They didn't re-explain the same concepts in English, to make sure that learners understand the information in English because assessment is in English (Student reflective journal, September 2014).

The responses suggest that learners are used to particular ways of teaching and learning, which for pre-service teachers appear problematic because teaching and learning means participation in class and not only focussing on the textbook. It appears that student uneasiness is shaped by the internalised knowledge, instruction and training they received in teacher education programmes during university courses (Schaffer, Gleich-Bope and Copich 2014). In addition, 
the language of teaching and learning is of concern because learners seem uncomfortable speaking English in class, including grade 12 learners. The perception of 'English as difficult' is possibly shaped by teachers who also use Se-Tshonga during teaching and learning, which is problematic considering that assessment happens in the English language. Learners are expected to engage with content and concepts in English, and if they think of English as difficult it is inconceivable whether and how they learn for understanding in different subjects. Alford (2013) states that teachers and schools are responsible for developing student competence and confidence as they progress through school, and this can happen if teachers are also confident speaking in English.

In addition to sharing teaching strategies, pre-service teachers suggested having meetings with in-service teachers at the end of every week, that is, Fridays, to keep the conversations open for improvement. According to the student teachers, they would have liked to discuss their observation experiences of in-service teachers and also get feedback from the mentoring teachers about their observation of pre-service teachers.

My supervising teacher complained about my teaching approach, saying that I should only use a textbook because learners are used to that. She said 'just ask them to open the textbook, all the information is there.' I don't have a problem with using a textbook, but that knowledge need to be explained further for learners to understand it in different ways ... (Student reflective journal, September 2014).

It would have been very nice to have group discussions with teachers about our observation of their teaching, and also explain what they think of our teaching, where and how to improve before my lesson critique (Student group discussion session, September 2014).

It seems that there were different teaching approaches between the pre-service and in-service teachers, and the supervising teacher wanted learners to be taught in a particular way. Ferber and Nillas (2010) talks about the different challenges that student teachers experience while on teaching experience, such as different aspects of the skills demonstrated by professional teachers, communication, classroom management, or instructional delivery. Most importantly, Marks (2007) states that supervising teachers represent obstacles that impede the implementation of university teachings, especially when the philosophy or the demands of the supervising teacher differ from that of the university. It becomes challenging for pre-service teachers as they want to meet the expectations of the university, while at the same time meeting the supervising teacher's expectations. This sometimes happens even when the university lecturer explains the expectations of the university to the supervising teachers, but the latter appears to want to do things their way. 


\section{RESTRUCTURING THE RTE PROJECT: WITS DREAM TEAM}

To be able to work with the teachers continuously to enhance the school and learners' performance, pre-service teachers suggested ways to improve Wits rural teaching experience. Instead of focussing only on second- and third-year students for rural teaching experience, students suggested that the project include fourth-year students.

We understand the purpose of the project to provide this opportunity to as many students as possible, which means the project need to be expanded from 10 students to at least 30 students per year. We want to make an impact in the schools, to learners, with teachers, and the community .... We must start a Wits dream team to be known in Acornhoek and the whole Bushbuckridge area (Student group discussion session, September 2014).

I worked with grade 8 and 9 and I noticed that learners need lot of one on one engagement in maths and English, but not enough time and students. If there were four or five of us in that school with the same specialisations, then it was going to be easy to work effectively with learners and teachers. So the project should start from second year until fourth year, working with the teachers and learners, to see if we make a difference in three years than three weeks (Student group discussion session, May 2015).

I observed foundation phase teachers, grade 2 and 3 especially, there is more to be done there. I am not saying I have all the answers, but with the knowledge and ideas we have from the university, I think we can make a difference to improve learners' reading and writing skills. They need special attention, they are behind with their reading and writing skills. So, definitely continuation is important to work with teachers and grow together by helping each other and learners gain (Student group discussion session, May 2015).

The pre-service teachers appreciated the opportunity of rural teaching experience (TE), and suggested that taking more students from second to fourth years for three years might create a better relationship between the schools and the university than the current three weeks. Furthermore, the recommendation to start a dream team seems to be shaped by the observation in foundation phase and the challenges that teachers and learners experience. There is a belief that establishing a relationship between Wits School of Education and Acornhoek, especially the schools, might enhance teaching and learning. While the student teaching experience is 'the opportunity to stand face to face with the challenges and demands of the teaching profession' (Ferber and Nillas 2010,63), this group of students appear to have realised that the challenges experienced in rural schools and classrooms are lessons worth learning. It is because of these experiences that they want to extend the project into a longitudinal project rather than a short project projecting them as 'tourists' and 'explorers'.

\section{CONCLUSION}

The article presented pre-service teachers' information about their experiences in rural schools, and also their perceptions of students' rural teaching experience as it stands. Pre-service teachers feel it is important not to be perceived as privileged students: they want opportunities 
to interact and work with the community to create better understanding. It is not only the concept of 'rural teaching experience' that is interrogated, the current accommodation arrangement is problematised by student teachers because it causes distantiation from the 'reality' of rural community. The notion of community partnerships to make a difference is important for the student teachers, which is possibly in line with the teaching profession that promotes community development through partnership. Lack of opportunities to do all these appears to frustrate student teachers because for them it does not mean they have been part of the rural community. Of importance for pre-service teachers is to work as a team with teachers for holistic improved performance in rural schools. The student teachers suggested the creation of a 'dream team' to partner with the community, especially in collaboration with teachers and learners, for further development and improved performance in schools.

\section{NOTE}

At the beginning of the project I worked with my colleague, and as the years progressed we decided not to go together to conduct rural teaching experience (RTE) due to expense, and with only 10 or 11 students per teaching experience, one staff member was sufficient.

\section{REFERENCES}

Alford, S. F. 2013. The relationship of preservice teachers to English language learners in mainstream classrooms. Unpublished Doctoral dissertation, University of Nebraska-Lincoln, NE.

Arends, F. and M. Phurutse. 2009. Beginner teachers in South Africa: School readiness, knowledge and skills. Cape Town: HSRC Press.

Balfour, R., C. Mitchell and R. Moletsane. 2008. Troubling contexts: Toward a generative theory of rurality as education research. Journal of Rural and Community Development 3(3): 100-111.

Boylan, C. and D. McSwan. 1998. Long-staying rural teachers: Who are they? Australian Journal of Education 42(1): 49-65.

Britzman, D. 2003. Practice makes practice: A critical study of learning to teach. (Revised edition). Albany, NY: State University of New York Press.

Butler, T. 2013. Review of the book: Rainbow pie: A redneck memoir, by J. Bageant, and Those who work, those who don't: Poverty, morality, and family in rural America, by J. Sherman. Journal of Research in Rural Education 28(5): 1-4. http://jrre.vmhost.psu.edu/wp-content/uploads/ 2016/01/28-5.pdf

Caires, S., L. Almeida and D. Vieira. 2012. Becoming a teacher: Student teachers' experiences and perceptions about teaching practice. European Journal of Teacher Education 35(2): 163-178.

Creswell, J. W. 2009. Research design: Qualitative, quantitative, and mixed methods approaches. 3rd Edition. Los Angeles: Sage Publications, Inc.

De Lange, N., M. Khau and L. Athiemoolam. 2014. Teaching practice at a rural school? 'And why should we go there?' South African Journal of Higher Education 28(3): 748-766.

De Vos, A. S. 2002. Combined qualitative and quantitative approach. In Research at grass roots: For the social sciences and human service professions, ed. A. S. de Vos, H. Strydom, C. B. Fouche and C. S. L. Delport. Pretoria: Van Schaik.

Dymant, J. E. and T. S. O’Connell. 2010. The quality of reflection in student journals: A review of 
limiting and enabling factors. Innovative Higher Education 35: 233-244.

Eckert, L. S. and R. Petrone. 2013. Raising issues of rurality in English teacher education. English Education 46(1): 68-81.

Eppley, K. 2009. Rural schools and the highly qualified teacher provision of no child left behind: A critical analysis. Journal of Research in Rural Education 24(4): 1-11.

Ferber, T. and L. A. Nillas. 2010. Through the eyes of student teachers: Success and challenges in field teaching experiences. National Teacher Education Journal 3(2): 61-86.

Field, M. 2001. Education crisis in the Pacific. The Fiji Times 5 May.

Good, T. L, M. McCaslin, H. Y. Tsang, J. Zhang, C. R. Wiley and A. R. Bozack. 2006. How well do $1^{\text {st }}$-year teachers teach. Does type of preparation make a difference? Journal of Teacher Education 57(4): 410-430.

Graham, S. 2006. Strategy instruction and the teaching of writing. A meta-analysis. In Handbook of Writing Research, ed. Charles A. MacArthur, Steve Graham, and Jill Fitzgerald, 187-207. The Guilford Press, ISBN 1-59385-190-1, New York, United States of America.

Green, B. and J. Reid. 2004. Teacher education for rural-regional sustainability: Changing agendas, challenging futures, chasing chimeras? Asia-Pacific Journal of Teacher Education 32(3): 255273.

Halsey, R. J. 2009. Australia's sustainability: A new policy front for rural education? Education in Rural Australia 19(2): 1-7.

HREOC, see Human Rights and Equal Opportunity Commission

Hudson, P. and S. Hudson. 2008. Changing preservice teachers' attitudes for teaching in rural schools. Australian Journal of Teacher Education 33(4): 67-77.

Human Rights and Equal Opportunity Commission. 2000. Recommendations: National inquiry into rural and remote education. Human Rights and Equal Opportunity Commission: Sydney.

Junqueira, K. and S. Matoti. 2013. A comparative study of pre-service teachers' teaching efficacy beliefs before and after work integrated learning: Part two. Africa Education Review 10(1): 28-46.

Lamote, C. and N. Engels. 2010. The development of student teachers' professional identity. European Journal of Teacher Education 33(1): 3-18.

Lingam, G. I. 2004. Teacher preparation for the world of work: A study of pre-service primary teacher education in Fiji. Unpublished PhD thesis, Griffith University, Brisbane, Australia.

Lingam, G. I. 2012. Preparing teachers for rural schools: An empirical evidence from a Fiji case. Greener Journal of Educational Research 2(2): 1-12.

Mann, K., J. Gordon and A. MacLeod. 2009. Reflection and reflective practice in health professions education: a systematic review. Advances in Health Sciences Education, 14(4), 595-621.

Maphalala, M. C. 2013. Understanding the role of mentor teachers during teaching practice session. International Journal of Educational Sciences 5(2): 123-130.

Maree, K. 2007. First steps in research. Pretoria: Van Schaik Publishers.

Marks, M. J. 2007. Influences on preservice teacher socialization: A qualitative study. Paper presented at the American Educational Research Association Annual Meeting Chicago, IL.

Masinire, A., F. Maringe and T. Nkambule. 2014. Education for rural development: Embedding rural dimensions in initial teacher preparation. Perspectives in Education Journal 32(3): 146-158.

Mayer, J. D., P. Salovey and D. R. Caruso. 2004. Emotional intelligence: Theory, findings and implications. Psychological Inquiry 60: 197-215.

Miller, L. C. 2012. Understanding rural teacher recruitment and the role of community amenities. Journal of Research in Rural Education 27(13): 1-52.

Moletsane, R. 2012. Repositioning educational research on rurality and rural education in South Africa: Beyond deficit paradigms. In Rural education and rural realities: The politics and possibilities of 
rural research in Southern Africa. Perspectives in Education Journal 30(1): 1-9.

Mukeredzi, T. G. and A. R. Mandrona. 2013. The journey to becoming professionals: Student teachers' experiences of teaching practice in a rural South African context. International Journal of Educational Research 62: 141-151.

Schaffer, C., D. Gleich-Bope and C. B. Copich. 2014. Urban immersion: Changing pre-service teachers' perceptions of urban schools. The Nebraska Educator: A Student-Led Journal Paper 19.

Schafft, K. A. and A. Y. Jackson. (Ed.). 2010. Rural education for the twenty-first century: Identity, place, and community in a globalizing world. University Park, PA: The Pennsylvania State University Press.

Tsang, A. 2011. In-class reflective group discussion as a strategy for the development of students as evolving professionals. International Journal for the Scholarship of Teaching and Learning 5(1): $1-20$.

Wenger, K. J. and J. Dinsmore. 2005. Preparing rural teachers for diversity. Journal of Research in Rural Education 20(10): 1-10.

White, S. and J. Reid. 2008. Placing teachers? Sustaining rural schooling through place-consciousness in teacher education. Journal of Research in Rural Education 23(7): 1-11.

Wright, D. and J. Osborne. 2007. Preparation for teaching in rural schools. Paper presented at the British Educational Research Association Annual Conference, Institute of Education, University of London. http://www.leeds.ac.uk/educol/documents/165077.htm

UNESCO. 1995. Debate on educational policy 1993: Reflections and proposals. Paris: UNESCO. 